\title{
Carbothermic Reduction of Zinc Containing Industrial Wastes: A Kinetic Model
}

\author{
M. LEUCHTENMUELLER, C. LEGERER, U. BRANDNER, and J. ANTREKOWITSCH
}

\begin{abstract}
Effective recycling of zinc-containing industrial wastes, most importantly electric arc furnace dust, is of tremendous importance for the circular economy of the steel and zinc industry. Herein, we propose a comprehensive kinetic model of the combined carbothermic and metallothermic reduction of zinc oxide in a metal bath process. Pyro-metallurgical, large-scale lab experiments of a carbon-saturated iron melt as reduction agent for a molten zinc oxide slag were performed to determine reaction constants and accurately predict mass transfer coefficients of the proposed kinetic model. An experimentally determined kinetic model demonstrates that various reactions run simultaneously during the reduction of zinc oxide and iron oxide. For the investigated slag composition, the temperature-dependent contribution of the metallothermic zinc oxide reduction was between 25 and $50 \mathrm{pct}$ of the overall reaction mechanism. The mass transfer coefficient of the zinc oxide reduction quadrupled from $1400{ }^{\circ} \mathrm{C}$ to $1500{ }^{\circ} \mathrm{C}$. The zinc recovery rate was $>99.9$ pct in all experiments.
\end{abstract}

https://doi.org/10.1007/s11663-020-02047-9

(C) The Author(s) 2021

\section{INTRODUCTION}

ZINC ( $\mathrm{Zn})$ is the fourth most produced metal worldwide (13 million tons per year) following iron, aluminum and copper. The applications of zinc range from predominately galvanizing steel, over brass alloy products, to super pure zinc oxide. ${ }^{[1]}$ Despite its widespread use, $\mathrm{Zn}$ has a rare abundance of only $70 \mathrm{ppm}$ in the earth's crust (e.g. abundance of $\mathrm{Fe} 5.63$ pct and Al 8.23 pct), which emphasis the importance of a resource-conserving usage focused on the mitigation of production and recycling losses. ${ }^{[2]}$ Yet, the global end-of-life recycling rate of $\mathrm{Zn}$ is a mere 33 pct, where the largest part of $\mathrm{Zn}$ losses occur during waste management, causing excessive, potentially hazardous $\mathrm{Zn}$ emissions. ${ }^{[3]}$ In addition, low efficiencies of existing recycling technologies further exacerbate the low $\mathrm{Zn}$ recycling rate, and highlight the tremendous need to improve $\mathrm{Zn}$-containing industrial waste recycling processes. $^{[4-7]}$

M. LEUCHTENMUELLER, U. BRANDNER, and J. ANTREKOWITSCH are with the Chair of Non-Ferrous Metallurgy, Montanuniversität Leoben, Franz-Josef-Strasse 18, 8700 Leoben, Austria. Contact e-mail: manuel.leuchtenmueller@ unileoben.ac.at C. LEGERER is with the Rural Clinical School, Faculty of Medicine, University of New South Wales, Sydney, NSW 2052, Australia.

Manuscript submitted May 5, 2020; accepted December 3, 2020.

Article published online January 6, 2021.
Main Zn-containing industrial wastes are leaching residues and jarosite from primary zinc production, lead slags and electric arc furnace dust (EAFD). ${ }^{[6,8-10]}$ EAFD is a waste material of steel recycling that contains up to 43 pct of $\mathrm{Zn} \cdot{ }^{[11]}$ In steel recycling, scrap steel is melted at high temperatures in an electric arc furnace (EAF). During this process volatile elements including $\mathrm{Zn}$ from galvanized steel scrap evaporate and ultimately accumulate as EAFD. Other elements present in EAFD are $\mathrm{Fe}, \mathrm{Pb}, \mathrm{Cd}, \mathrm{Na}, \mathrm{K}$, halides and slag building compounds such as $\mathrm{CaO}$ and $\mathrm{SiO}_{2}{ }^{[12]}$ In 2018 , the global steel production was 1807 million tons (MT), 520 MT of which were produced via the EAF route. ${ }^{[13]}$ Per ton of liquid EAF steel ${ }^{[14-16]} 10$ to $25 \mathrm{~kg}$ of EAFD are typically generated (depending on scrap composition and furnace operation, $\left.{ }^{[12,17]}\right)$ which sum to approximately a yearly EAFD generation of 5.2 to $13 \mathrm{MT}^{[18]}$ Moreover, the EAF steel production is forecasted to increase up to $1000 \mathrm{MT}$ in 2050, in which case the annual dust generation could increase up to $25 \mathrm{MT} \cdot{ }^{[19]}$ Given such substantial quantities and the high average $\mathrm{Zn}$-content, EAFD is a considerable secondary resource of valuable Zn.

Despite the high $\mathrm{Zn}$ content, less than 50 pct of the generated EAFD is recycled globally, ${ }^{[18]}$ and in most developed countries EAFD is classified as hazardous waste (US EPA: K061, ${ }^{[20]}$ European Waste Catalogue (EWC) $1002 \quad 07 *[21]$ and Ministry of Environment in Canada $143 \mathrm{H}^{[22]}$ ), due to its high heavy metal concentrations. Environmental regulations in the US, EU and Canada therefore require stabilization treatment, before EAFD can be landfilled, which contributes significantly 
to the EAFD disposal costs. The high specific volume and concomitant low bulk density (1.1 to $\left.2.5 \mathrm{~g} / \mathrm{cm}^{3}\right)$ of EAFD further contribute to the ecologic impact and land filling related costs of EAFD. ${ }^{[6]}$ As a result, EAFD is predominantly recycled in jurisdictions where environmental policies demand low leachability and prohibit cost-efficient landfilling. The most successful recycling processes for EAFD are based on a carbothermic high-temperature reduction reaction.

\section{CARBOTHERMIC EAFD RECYCLING PROCESSES}

The fundamental chemical principle of zinc recovery from EAFD is identical in all industrial pyro-metallurgical processes: $\mathrm{ZnO}$ is carbothermically reduced to $\mathrm{Zn}$, which then volatilizes into the gas phase. After leaving the reaction zone gaseous $\mathrm{Zn}$ is typically combusted to $\mathrm{ZnO}$, which is subsequently captured in bag house filters. The main impurities of the obtained crude zinc oxide $(\mathrm{CZO})$ are other volatile elements originating in EAFD: $\mathrm{Pb}, \mathrm{Cd}, \mathrm{K}, \mathrm{Na}, \mathrm{Cl}, \mathrm{F}$. In a final processing step the $\mathrm{CZO}$ is washed to remove chlorides and ultimately used as a secondary resource in the primary zinc industry.

Currently available EAFD recycling processes can be classified according to the physical state of the reactants, $\mathrm{ZnO}$ and $\mathrm{C}$. In the most commonly used Waelz kiln, RHF and MHF, the pyro-chemical reaction is a solid-solid reduction between carbon and $\mathrm{ZnO}$ or a solid-gaseous reaction between $\mathrm{CO}$ and $\mathrm{ZnO} .^{[23,24]}$ Other furnaces to treat EAFD are the electric arc, plasma and induction furnace, in which the reduction reaction is of (1) the solid-liquid type between coke and $\mathrm{ZnO}$ dissolved in a molten slag phase or of (2) the liquid-liquid type between dissolved carbon in the metal and $\mathrm{ZnO}$ in the slag. ${ }^{[25-27]}$

These underlying reaction types have a critical impact on the performance of EAFD recycling methods. Processes based on solid-solid reactions demonstrate relatively low $\mathrm{Zn}$ recovery rates, slow reaction kinetics which require large kiln dimensions (incurring high capital costs and heat losses), and generate a slag that is commonly landfilled. In comparison, processes with underlying liquid-liquid reaction mechanisms are usually performed at elevated temperatures showing faster reaction kinetics, lower capital costs and improved economic flexibility due to the production of a marketable slag phase as an additional production. ${ }^{[28]}$ But these processes are more energy intensive and exhibit increased refractory wear and therefore operating costs. Consequently, the lower overall energy consumption of the solid-solid reaction in connection with the counter-current operation mode are the decisive determinants for the uncontested success of the Waelz kiln process to recycle EAFD to date. Nonetheless, the Waelz kiln as the current state-of-the-art processes is far from optimal. For example, the Waelz kiln only demonstrates $\mathrm{Zn}$ recovery rates of roughly 85 pct, leaving room for progress. Table I lists process parameters for a typical Waelz kiln.
A significant amount of research has been conducted to find alternative concepts to the described C-based high-temperature EAFD recycling process. Investigated approaches range from $\mathrm{Zn}$ volatilization with halogenation $^{[34]}$ over hydrometallurgical approaches ${ }^{[35,36]}$ to physical separation processes, such as magnetic and air separation $^{[37,38]}$ and combinations of pyro- and hydrometallurgical approaches. ${ }^{[39,40]}$ However, due to the complex morphology of EAFD, these alternatives demonstrated either insufficient recovery rates or industrial viability compared to the state-of-art process. ${ }^{[41,42]}$

An initial step towards improvement of conventional, carbothermic processes (e.g. recovery rates) and development of new solutions require a more detailed understanding of the underlying reaction mechanisms and kinetics. In 1996, Donald and Pickles demonstrated a $\mathrm{Zn}$ recovery rate of almost 100 pet for a liquid-liquid concept in which a carbon-saturated iron melt is used as reduction agent to recycle EAFD. ${ }^{[15]}$ The reported reaction mechanism (Eqs. [1] to [3]) describes the high-temperature reduction of $\mathrm{ZnO}$ and $\mathrm{FeO}$ with dissolved carbon, ${ }^{[43]}$ and the metallothermic reduction of $\mathrm{ZnO}$ with liquid Fe. ${ }^{[44]}$

$$
\begin{gathered}
\mathrm{ZnO}_{1, \text { slag }}+\mathrm{C}_{1, \text { metal }} \rightarrow \mathrm{Zn}_{\text {gas }}+\mathrm{CO}_{\text {gas }} \\
\mathrm{FeO}_{1, \text { slag }}+\mathrm{C}_{1, \text { metal }} \rightarrow \mathrm{Fe}_{1, \text { metal }}+\mathrm{CO}_{\text {gas }} \\
\mathrm{ZnO}_{1, \text { slag }}+\mathrm{Fe}_{1, \text { metal }} \rightarrow \mathrm{Zn}_{\text {gas }}+\mathrm{FeO}_{1, \text { slag }}
\end{gathered}
$$

Kinetic studies mainly exist for the solid-solid reduction of $\mathrm{ZnO}{ }^{[45-48]}$ but the reaction kinetics of the liquid-liquid $\mathrm{ZnO}$ reduction is poorly understood. Notably, the contribution of Fe to the overall reduction of $\mathrm{ZnO}$ with a C-saturated iron melt remains to be clarified. The goals of this paper, therefore, are twofold: (1) to postulate a comprehensive kinetic model helping to get a better understanding of how the constituents within the metal and slag phase react, and (2) to determine concomitant model parameters based on high-temperature experiments to accurately describe the reaction kinetics of the $\mathrm{ZnO}$ and $\mathrm{FeO}$ reduction. Finally, we also present mass transfer coefficients for the $\mathrm{ZnO}$ and $\mathrm{FeO}$ reduction accounting for all experimental assumption to assist the development of industrial EAFD recycling processes.

\section{MATERIALS AND METHODS}

\section{A. Source Materials and Experimental Setup}

The reduction mechanism between liquid $\mathrm{ZnO}$ and carbon dissolved in liquid Fe was studied in controlled experimental conditions by continuous monitoring of compositions and temperature. A synthetic slag, a C-saturated iron alloy and pure $\mathrm{ZnO}$ (>99 pct) were melted in a graphite crucible (inner-diameter $180 \mathrm{~mm}$, inner-height $270 \mathrm{~mm}$, wall thickness $30 \mathrm{~mm}$ ) which was heated by an induction furnace (max. power input 80 
kW; ITG Induktionsofenanlagen GmbH, Hirschhorn, Germany). Figure 1 illustrates the reaction mechanism and gives an overview of the experimental setup.

Prior to the reduction experiment a carbon-saturated iron master alloy was prepared by adding graphite to S235 construction steel. In a similar way a slag was prepared by remelting pure quartz, lime, and alumina. The ratio between $\mathrm{CaO}$ and $\mathrm{SiO}_{2}$ 1.2. To lower the liquidus temperature of the system, $\mathrm{Al}_{2} \mathrm{O}_{3}$ was added. According to FactSage calculations, the lowest possible liquidus temperature in slag system is reached at around 16 pct $\mathrm{Al}_{2} \mathrm{O}_{3}$. The final composition of the prepared slag was 38.4 pet $\mathrm{SiO}_{2}, 47.5$ pet $\mathrm{CaO}$ and 14.1 pet $\mathrm{Al}_{2} \mathrm{O}_{3}$. The detailed procedure for six high-temperature reduction experiments included the following steps:

1. Preheating of the graphite crucible to the desired temperature $\left(1420{ }^{\circ} \mathrm{C}\right.$ to $\left.1530{ }^{\circ} \mathrm{C}\right)$

2. Feeding of the iron master alloy and the synthetic slag mixture

3. Melting and temperature homogenization

4. Feeding of the pure $\mathrm{ZnO}$ (>99 pct)

5. Slag sampling in defined time intervals

6. Temperature reference measurements to calibrate the pyrometer (a minimum of three)

7. Chemical analysis of slag samples

The graphite crucible was covered by a perforated cover (hole diameter $60 \mathrm{~mm}$ ) to prevent excessive heat losses and achieve a homogenous temperature distribution across the melt. At the bottom of the furnace a pyrometer continually recorded the crucible surface temperature. A custom-made furnace controller (PID algorithm) regulated the furnace power to ensure a constant crucible temperature and therefore isothermal conditions within the crucible. Additionally, three to four temperature measurements per experiment were recorded with commercially available type-S immersion thermocouples (Minkon GmbH, Erkrath, Germany), these measurements were used in the kinetic model.

After cooling to room temperature, the slag samples were ground in a vibration mill, fixed to adhesive tape and analyzed using energy-dispersive X-ray spectroscopy within a scanning electron microscope. The chemical analyses were recalculated and normalized to account for the corresponding oxidic forms $(\mathrm{Ca}$ to $\mathrm{CaO}$, Si to $\mathrm{SiO}_{2}, \mathrm{Al}$ to $\mathrm{Al}_{2} \mathrm{O}_{3}, \mathrm{Zn}$ to $\mathrm{ZnO}$ and $\mathrm{Fe}$ to $\mathrm{FeO}$ ) of the measured elements.

The reduction of $\mathrm{ZnO}$ from the slag and the $\mathrm{Fe}$ oxidation into the slag influence the total slag mass and consequently the chemical analysis. To account for these changes in the kinetic model, effective $\mathrm{FeO}$ and $\mathrm{ZnO}$ concentrations (Figure 2) are calculated in Eqs. [4] and [5]. The measured $\mathrm{FeO}$ and $\mathrm{ZnO}$ concentrations are multiplied with the ratio of slag building compounds at the start $(t=0)$ and each sampling time $(t)$. The effective $\mathrm{FeO}$ and $\mathrm{ZnO}$ concentrations are subsequently denoted as $[\mathrm{ZnO}]$ and $[\mathrm{FeO}]$.

$$
\begin{aligned}
{[\mathrm{ZnO}] } & =\text { Effective_ZnO } \mathrm{ZnO}_{(t)} \\
& =\text { Measured_ZnO } \mathrm{ZnO}_{(t)} \frac{\left(\mathrm{SiO}_{2}+\mathrm{Al}_{2} \mathrm{O}_{3}+\mathrm{CaO}\right)_{t=0}}{\left(\mathrm{SiO}_{2}+\mathrm{Al}_{2} \mathrm{O}_{3}+\mathrm{CaO}\right)_{t}}
\end{aligned}
$$

$$
\begin{aligned}
{[\mathrm{FeO}] } & =\text { Effective__FeO } \\
& =\text { Measured_FeO } \\
& \\
(t) & \frac{\left(\mathrm{SiO}_{2}+\mathrm{Al}_{2} \mathrm{O}_{3}+\mathrm{CaO}\right)_{t=0}}{\left(\mathrm{SiO}_{2}+\mathrm{Al}_{2} \mathrm{O}_{3}+\mathrm{CaO}\right)_{t}}
\end{aligned}
$$

Table I. Typical Process Parameters for Waelz Kilns ${ }^{[24,29-33]}$

\begin{tabular}{lccccc}
\hline Slag & Length & Diameter & Carbon & CO $_{2}$ & Zn in Slag \\
\hline 560 to $650 \mathrm{~kg}$ & 38.5 to $60.0 \mathrm{~m}$ & 3.0 to $4.2 \mathrm{~m}$ & 160 to $200 \mathrm{~kg} /$ ton EAFD & 580 to $730 \mathrm{~kg} /$ ton EAFD & $\sim 5 \mathrm{pct}$ \\
\hline
\end{tabular}
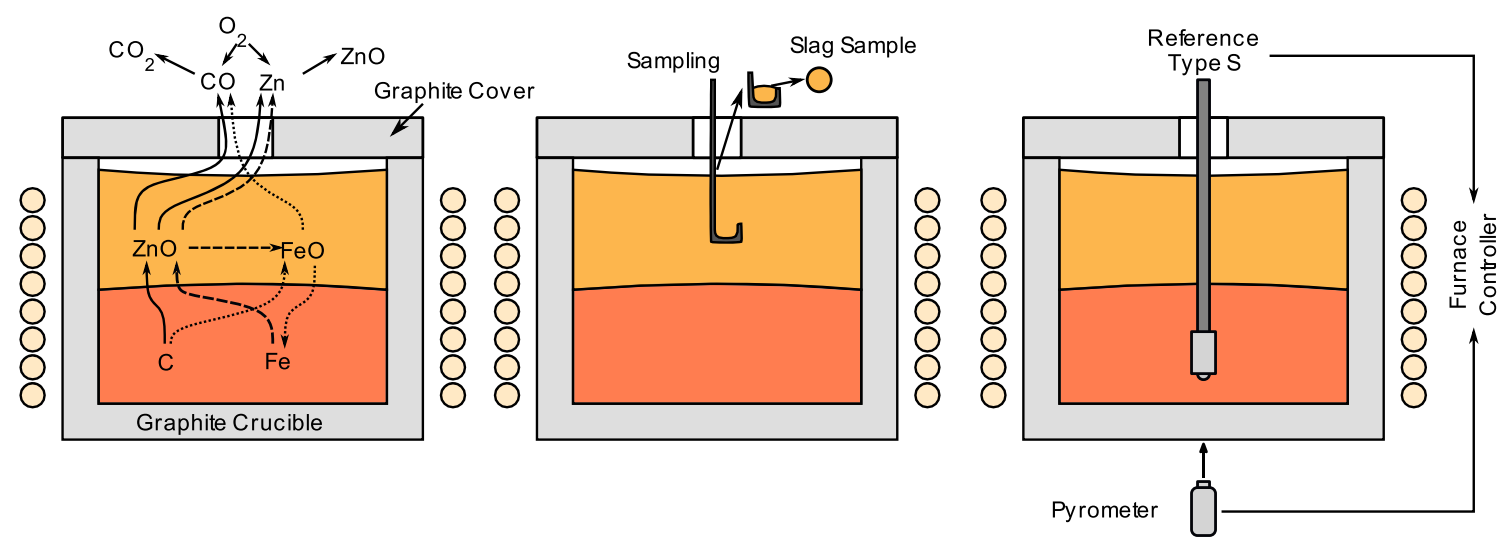

Fig. 1-Overview of the reaction mechanism and experimental setup, sampling procedure and temperature reference measurements. 


\section{B. Kinetic Model}

In physical chemistry, kinetic models describe the effect of chemical kinetics on the rate of a reaction. As such, mathematical models of reaction kinetics are frequently applied to optimize process conditions (e.g. temperature and pressure) and product yield in the design or modification of chemical reactors. In the following we present the construction of a mathematical model that describes in detail the characteristics of the reduction reactions between a carbon-saturated iron melt and a synthetic slag system containing $\mathrm{ZnO}$. The presented approach establishes reaction rates for the reaction mechanism (Eqs. [1] to [3]) and combines the resulting partial differential equations to yield a depended system of linear ordinary differential equations (ODE). Obtained isothermal experimental data can be fitted to respective ODEs, yielding rate constants for $\mathrm{FeO}$ and $\mathrm{ZnO}$. A combination of these individual rate constant with the Arrhenius equation allows the calculation of temperature dependent rate constants. To account for other process conditions, mass transfer coefficients for both reactants are stated. In summary, this kinetic model expands on the concept of a liquid carbon-saturated iron melt used to recycle $\mathrm{Zn}$-containing waste material (e.g. EAFD) ${ }^{[22]}$ which is determined by two carbothermic reactions underpinning the reduction of $\mathrm{ZnO}$ and $\mathrm{FeO}$ (Eqs. [1] to [2]) and a metallothermic reaction between $\mathrm{Fe}$ and $\mathrm{ZnO}$ (Eq. [3]).

The net reaction rate of each chemical reactions is defined as the difference between the rate of reaction and reverse reaction (Eq. [6]). When the rate of reaction and reverse reaction are identical, the net reaction rate is zero and the reaction has reached an equilibrium state.

$$
\begin{aligned}
\text { Net reaction rate }= & \text { Reaction rate } \\
& - \text { Reversereactionrate }
\end{aligned}
$$

The net reaction rate for the reduction reaction between liquid $\mathrm{FeO}$ and carbon dissolved in liquid metal (shown in Eq. [2]) is described as follows:

$$
-\frac{\mathrm{d}[\mathrm{FeO}]}{\mathrm{d} t}=k_{\mathrm{FeO}-\mathrm{C}}^{\prime} \cdot(\mathrm{C}) \cdot[\mathrm{FeO}]-k_{\mathrm{FeO}-\mathrm{oxi}}^{\prime} \cdot(\mathrm{Fe}) \cdot\{\mathrm{CO}\}
$$

where $k_{\mathrm{FeO}-\mathrm{C}}^{\prime}$ and.$k_{\mathrm{FeO}-\mathrm{oxi}}^{\prime}$ correspond to the kinetic constants (rate constants) of the reaction and reverse reaction, respectively. The reaction rate is a product of $k_{\mathrm{FeO}-\mathrm{C}}^{\prime}$, the carbon concentration of the metal (C) and the $\mathrm{FeO}$ concentration in the slag $[\mathrm{FeO}]$. Conversely, the reverse reaction rate is proportional to $k_{\mathrm{FeO}-\mathrm{oxi}}^{\prime}$, the Fe-concentration in the metal $(\mathrm{Fe})$, the $\mathrm{CO}$ partial pressure at the phase boundary $\{\mathrm{CO}\}$.

The continuous consumption of carbon according to Eqs. [1] and [2] would allow the conclusion of a dropping carbon concentration. However, the reduction process was performed in a graphite crucible, which is why the carbon concentration was assumed to be constant. Similarly, the assumption was made that Fe concentration in the metal bath would remain nearly constant. Additionally, the process slag was held at a stable level resulting in a steady partial pressure of developing $\mathrm{CO}$ gas bubbles. These assumptions are considered by the simplified rate constants $k_{\mathrm{FeO}-\mathrm{C}}$ and $k_{\mathrm{FeO}-\mathrm{Oxi}}$ :

$$
-\frac{\mathrm{d}[\mathrm{FeO}]}{\mathrm{d} t}=k_{\mathrm{FeO}-\mathrm{C}} \cdot[\mathrm{FeO}]-k_{\mathrm{FeO}-\mathrm{Oxi}}
$$

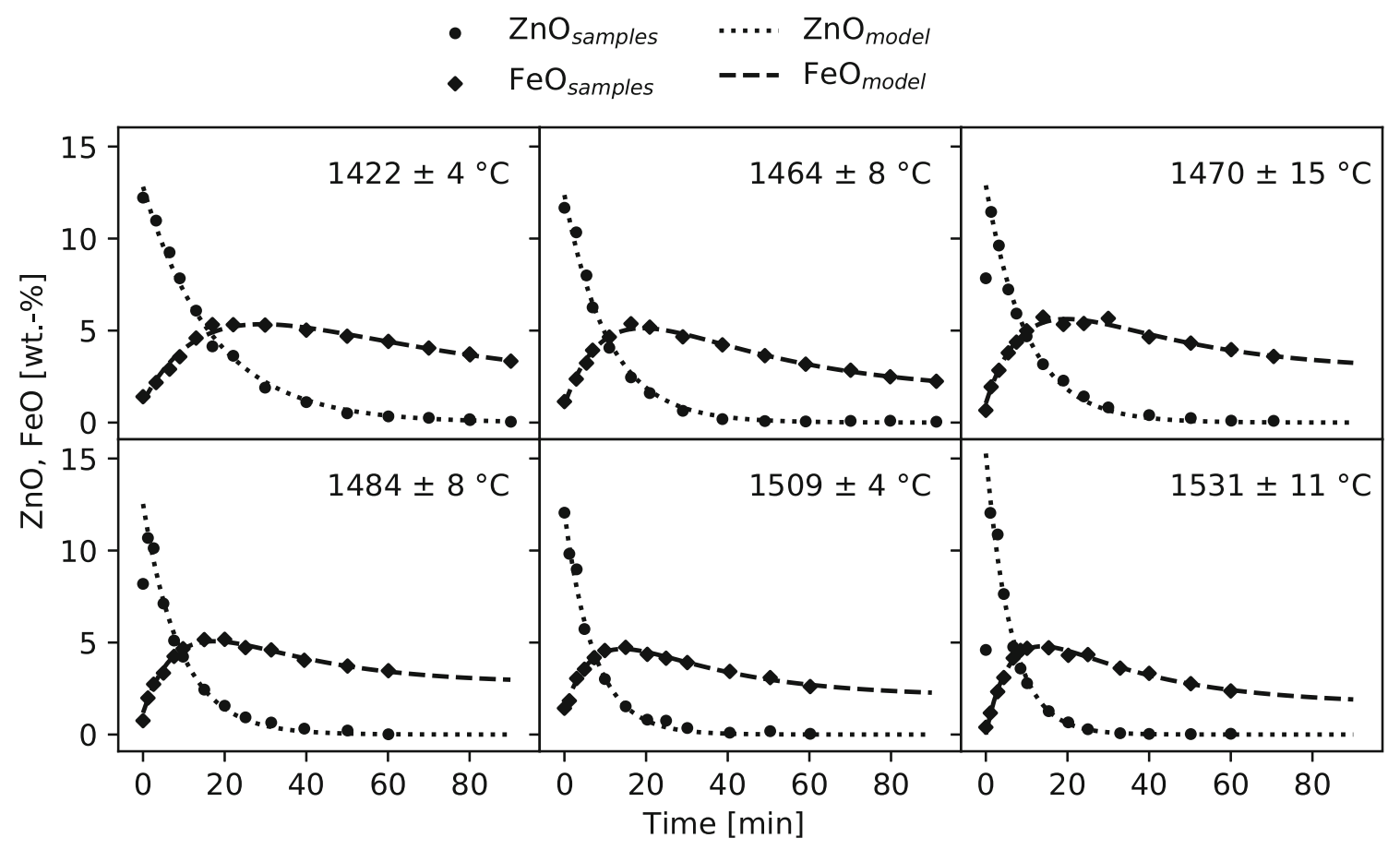

Fig. 2-Measured $\mathrm{FeO}$ and $\mathrm{ZnO}$ concentrations plotted over time compared to fitted equations for six isothermal experiments at increasing temperatures; insert: average and deviation of temperature measurements (type-S immersion thermocouple). 
The same procedure is used to simplify the net reaction rate of the $\mathrm{ZnO}$ reduction (Eq. [1]) and the metallothermic reaction between $\mathrm{Fe}$ and $\mathrm{ZnO}$ (Eq. [3]). In the prior reaction, gaseous $\mathrm{Zn}$ leaves the reaction zone during the first stage of the reaction and therefore, allow for the assumption of non-reversibility. ${ }^{[49]}$ Equation [10] highlights that the resulting reaction rates of the metallothermic reaction are linked by the $\mathrm{FeO}$ to $\mathrm{ZnO}$ molar mass ratio.

$$
\begin{gathered}
-\frac{\mathrm{d}[\mathrm{ZnO}]}{\mathrm{d} t}=k_{\mathrm{ZnO}-\mathrm{C}} \cdot[\mathrm{ZnO}] \\
-\frac{\mathrm{d}[\mathrm{ZnO}]}{\mathrm{d} t}=\frac{\mathrm{d}[\mathrm{FeO}]}{\mathrm{d} t} \cdot \frac{M_{\mathrm{FeO}}}{M_{\mathrm{ZnO}}}=k_{\mathrm{ZnO}-\mathrm{Fe}} \cdot[\mathrm{ZnO}]
\end{gathered}
$$

Subsequently, the combined reaction rates of $\mathrm{FeO}$ and $\mathrm{ZnO}$, which describe the interdependence between all three reduction reactions (Eqs. [1] to [3]) is derived:

$$
\begin{aligned}
-\frac{\mathrm{d}[\mathrm{FeO}]}{\mathrm{d} t}= & k_{\mathrm{FeO}-\mathrm{C}} \cdot[\mathrm{FeO}]-k_{\mathrm{Fe}-\mathrm{Oxi}}-k_{\mathrm{ZnO}-\mathrm{Fe}} \cdot[\mathrm{ZnO}] \\
& \cdot \frac{M_{\mathrm{ZnO}}}{M_{\mathrm{FeO}}}
\end{aligned}
$$

$$
-\frac{\mathrm{d}[\mathrm{ZnO}]}{\mathrm{d} t}=k_{\mathrm{ZnO}-\mathrm{C}} \cdot[\mathrm{ZnO}]+k_{\mathrm{ZnO}-\mathrm{Fe}} \cdot[\mathrm{ZnO}]
$$

Finally, the closed solution of this system of linear differential equations (DSolve method, Mathematica 11; Wolfram Research, IL) is given: area (= reaction area) to slag mass. In the present study, slag mass losses due to sampling and ongoing reactions are not considered. The assumption of a constant ratio of slag mass to phase boundary area is consequently used to calculate the mass transfer coefficient (MTC) for $\mathrm{FeO}$ and $\mathrm{ZnO}$ for the reaction mechanisms outlined in Eqs. [1] through [3].

The mass transfer coefficient (MTC) for a reaction mechanism $(j)$ is defined in Eq. [13], where $\left(k_{\mathrm{J}}\right)$ is the corresponding rate constant, $(A)$ the phase boundary area, $\left(M_{j}\right)$ the molar mass and $\left(m_{\text {slag }}\right)$ the slag mass:

$$
\mathrm{MTC}_{j}=k_{j} \cdot \frac{m_{\mathrm{slag}}}{A \cdot M_{j}}\left(\mathrm{~mol} \mathrm{~s}^{-1} \mathrm{~m}^{-}\right)
$$

\section{RESULTS}

Figure 2 illustrates effective $\mathrm{FeO}$ and $\mathrm{ZnO}$ concentrations (markers) for six isothermal experiments at increasing temperatures. Nonlinear regression was used to determine best-fit values for the four rate constants of Eq. I + II for each individual experiment and corresponding graphs are plotted.

At the beginning of each experiment the $\mathrm{FeO}$ concentration increased, pointing towards $\mathrm{Fe}$ oxidation (reverse reaction of Eq. [2]) and metallothermic $\mathrm{ZnO}$ reduction (Eq. [3]). Following the sharp initial decline of the $\mathrm{ZnO}$ concentration in the slag and at consequently lower $\mathrm{ZnO}$ compositions the carbothermic $\mathrm{FeO}$ reduction became more dominant, which lead to a steady decrease of the $\mathrm{FeO}$ concentration for the remaining experiment. Within the recorded experimental duration

$$
\begin{aligned}
& \mathrm{FeO}_{(t)}=\frac{e^{-k_{\mathrm{FeO}-\mathrm{C}} \cdot t}}{k_{\mathrm{FeO}-\mathrm{C}} \cdot\left(k_{\mathrm{FeO}-\mathrm{C}}-k_{\mathrm{ZnO}-\mathrm{C}}-k_{\mathrm{ZnO}-\mathrm{Fe}}\right)} \cdot \\
& \left(k _ { \mathrm { FeO } - \mathrm { C } } \cdot \left[[\mathrm{FeO}]_{0} \cdot\left(-k_{\mathrm{ZnO}-\mathrm{C}}+k_{\mathrm{FeO}-\mathrm{C}}-k_{\mathrm{ZnO}-\mathrm{Fe}}\right)-k_{\mathrm{ZnO}-\mathrm{Fe}} \cdot[\mathrm{ZnO}]_{0}+k_{\mathrm{ZnO}-\mathrm{Fe}} \cdot[\mathrm{ZnO}]_{0} \cdot e^{t \cdot\left(k_{\mathrm{FeO}-\mathrm{C}}-k_{\mathrm{ZnO}-\mathrm{C}}-k_{\mathrm{ZnO}-\mathrm{Fe}}\right)}\right.\right. \\
& \left.\left.-k_{\mathrm{FeO}-\mathrm{Oxi}}\right]+k_{\mathrm{FeO}-\mathrm{Oxi}} \cdot\left[k_{\mathrm{ZnO}-\mathrm{C}}\left(1-e^{k_{\mathrm{FeO}-\mathrm{C}} \cdot t}\right)+\cdot e^{k_{\mathrm{FeO}-\mathrm{C} \cdot t}}\left(k_{\mathrm{FeO}-\mathrm{C}}-k_{\mathrm{ZnO}-\mathrm{Fe}}\right)+k_{\mathrm{ZnO}-\mathrm{Fe}}\right]\right)
\end{aligned}
$$

$$
\mathrm{ZnO}_{(t)}=[\mathrm{ZnO}]_{0} \cdot e^{-\left(k_{\mathrm{ZnO}-\mathrm{C}}+k_{\mathrm{ZnO}-\mathrm{Fe}}\right) \cdot t}
$$

Resulting Eqs. [I] and [II] describe the time-dependent $\mathrm{FeO}$ and $\mathrm{ZnO}$ concentrations as a function of time, four temperature dependent rate constants $\left(k_{\mathrm{FeO}-\mathrm{C}}, k_{\mathrm{ZnO}-\mathrm{C}}, k_{\mathrm{ZnO}-\mathrm{Fe}}, k_{\mathrm{FeO}-\mathrm{Oxi}}\right)$ and the starting concentrations $\left(\mathrm{FeO}_{0}, \mathrm{ZnO}_{0}\right)$ at $\mathrm{t}=0$. The rate constants for $\mathrm{FeO}$ and $\mathrm{ZnO}$ can be approximated by the method of least squares to the experimental data. The rate constants are not solely determined by temperature and concentration, but also by the ratio of phase boundary (minimum 60 minutes) the $\mathrm{FeO}$ concentration did not reach a chemical equilibrium, which impacted the precise determination of the Fe oxidation rate constant, $k_{\text {Fe-Oxi }}$. Visual evaluations of the graphite crucibles after each experiment showed a lower crucible thickness in the metal area, due to dissolution of $\mathrm{C}$ in the liquid iron. This indicates that the reduction reaction predominantly occurs between the liquid metal and slag phase, rather than direct contact of graphite and slag. This agrees with unpublished experiments that only contain a molten slag (no metal bath), were the reduction reaction of $\mathrm{ZnO}$ was slow. 
By means of Arrhenius plots (Figure 3), the determined individual rate constants for all isothermal experiments were combined to generally valid, temperature dependent rate constants. The Arrhenius fit of the reduction mechanisms $\left(k_{\mathrm{FeO}-\mathrm{C}}, k_{\mathrm{ZnO}-\mathrm{C}}\right.$ and $\left.k_{\mathrm{ZnO}-\mathrm{Fe}}\right)$ demonstrated good correlation, whereas the Fe oxidation $\left(k_{\mathrm{Fe}-\mathrm{Oxi}}\right)$ does not follow the Arrhenius law. The reason are missing equilibrium conditions for the $\mathrm{FeO}$ reduction reaction in Figure 2 (the $\mathrm{FeO}$ concentration over time has always a significant slope after the last sample). Table II summarizes the found Arrhenius parameters. The activation energies were $285.7 \mathrm{~kJ} / \mathrm{mol}$ for $k_{\mathrm{ZnO}-\mathrm{C}}, 100.7 \mathrm{~kJ} / \mathrm{mol}$ for $k_{\mathrm{FeO}-\mathrm{C}}$ and $152.7 \mathrm{~kJ} / \mathrm{mol}$ for $k_{\mathrm{ZnO}-\mathrm{Fe}}$. In combination with the preexponential factor, these Arrhenius parameters present a general description of the rate constants with respect to the process temperature. Table III compares individual fitted rate constants (individual) with those calculated using the found Arrhenius parameters (general).

\section{A. Model Accuracy}

Scatter plots were used to correlate effective $\mathrm{FeO}$ and $\mathrm{ZnO}$ concentrations with values predicted by the developed kinetic model (Eq. I and II) comparing individual and general rate constants. Figures 4(a) and (b) illustrate the measured values against each individual isothermal model (Figure 2). The mean and standard deviation of the difference between measured and modeled $\mathrm{FeO}$ and $\mathrm{ZnO}$ values was $0.00 \pm 0.14$ wt pct and $-0.02 \pm 0.33 \mathrm{wt}$ pct, respectively. The deviation of measurements and modelled outcomes of the generalized kinetic model (after applying the Arrhenius equation) is depicted in Figures 4(c) and (d). Note, the average deviations for $\mathrm{FeO}$ and $\mathrm{ZnO}$ in the individual and general case remained roughly unchanged, which indicates the absence of a systematic error. When comparing

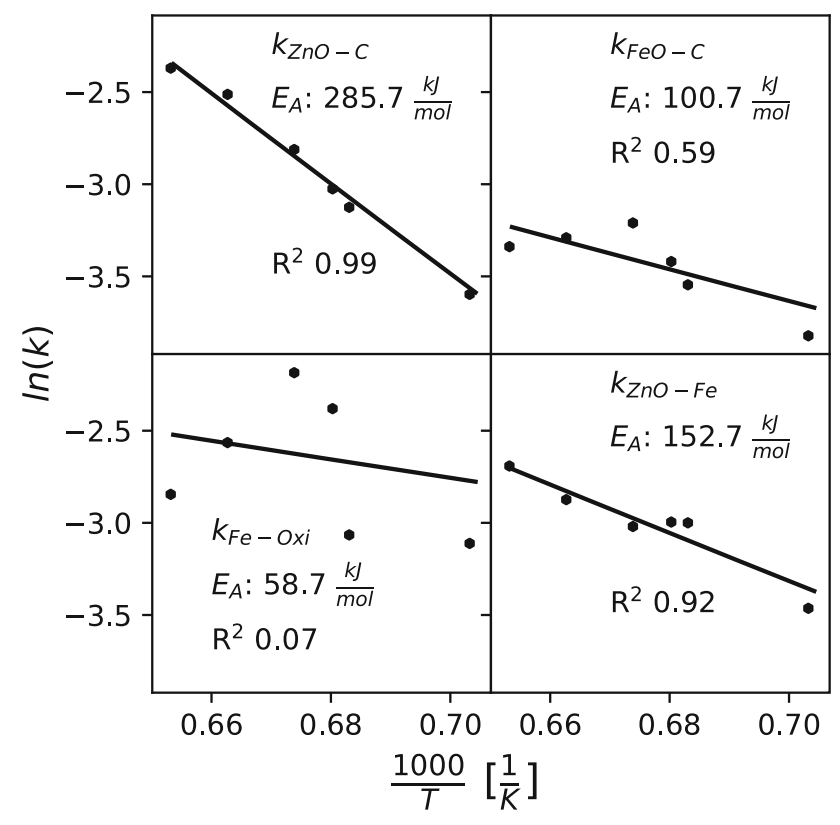

Fig. 3-Arrhenius plots for the rate constants of the kinetic model. the individual with the general model, the standard deviation for measured and modelled $\mathrm{FeO}$ concentrations was nearly doubled from 0.14 to $0.26 \mathrm{wt}$ pct. In contrast, the $\mathrm{ZnO}$ standard deviation remained at a roughly unchanged percentage. Similarly, the coefficient of determination decreases from 0.98 to 0.94 for $\mathrm{FeO}$ but stays same for $\mathrm{ZnO}$.

In summary, presented scatter plots demonstrate good correlation between the derived kinetic model and the experimental data. This suggests the suitability of applied approximations (constant slag mass, constant C-concentration in the metal, constant $\mathrm{CO}$ partial pressure) and validates the developed kinetic model to describe the reaction mechanism of the high-temperature $\mathrm{ZnO}$ and $\mathrm{FeO}$ reduction with dissolved $\mathrm{C}$.

\section{B. Mass Transfer Coefficient}

Finally, the mass transfer coefficient (MTC) for the $\mathrm{ZnO}$ reduction mechanisms was derived by recalculating the rate constants according to Eq. [13].

$$
\begin{gathered}
\mathrm{MTC}_{\mathrm{ZnO} \_\mathrm{C}}=3.94 \times 10^{8} \cdot e^{\frac{-285.7 \mathrm{~kJ} \mathrm{~mol}^{-1}}{R \cdot T}} \mathrm{~mol} \mathrm{~s}^{-1} \mathrm{~m}^{-2} \\
\mathrm{MTC}_{\mathrm{Zno} \_\mathrm{Fe}}=3.86 \times 10^{4} \cdot e^{\frac{-152.7 \mathrm{~kJ} \mathrm{~mol}-1}{R \cdot T}} \mathrm{~mol} \mathrm{~s}^{-1} \mathrm{~m}^{-2}
\end{gathered}
$$

Figure 5(a) highlights the threefold increase in overall MTC from $1400{ }^{\circ} \mathrm{C}$ to $1500{ }^{\circ} \mathrm{C}$ and visualizes the higher temperature dependency of the carbothermic mechanism compared to the metallothermic reaction. With rising temperatures the relative contribution of the carbothermic reaction to the overall reduction increased (Figure 5(b)). While both mechanisms equally influenced the overall reaction below $1400{ }^{\circ} \mathrm{C}$, the carbothermic reaction is dominant at elevated temperatures. The presented methodology is useful to estimate production volumes for given furnace dimensions, dust compositions and process conditions of a recycling treatment applying the iron-bath process.

\section{DISCUSSION}

Carbothermic reduction is the most successful mechanism to recycle $\mathrm{Zn}$ containing industrial wastes, such as EAFD. The widespread use of the Waelz kiln, however, exhibits considerable drawbacks, such as the improvable recovery rate (approx. $85 \mathrm{pct}$ ), the generation of Waelz slag and the high specific $\mathrm{CO}_{2}$ emissions. Donald and Pickles proposed an alternative concept to recycle EAFD with a carbon-saturated iron melt as reduction agent for $\mathrm{ZnO}{ }^{[22]}$ and successfully demonstrated a $\mathrm{Zn}$ recovery rate of almost 100 pct. In this study we have presented a mathematical kinetic model which describes the $\mathrm{ZnO}$ and $\mathrm{FeO}$ reduction with carbon dissolved in an iron melt. Pyro-metallurgical, large-scale lab experiments of a metal bath process to recover $\mathrm{Zn}$ from a molten slag phase were performed (1) to accurately describe the fundamental reaction kinetics and (2) to evaluate the contributions of the carbothermic and 
Table II. Summary of Determined Arrhenius Parameters for the Defined Reaction Mechanisms

\begin{tabular}{|c|c|c|c|c|}
\hline & $k_{\mathrm{ZnO}-\mathrm{C}}$ & $k_{\mathrm{FeO}-\mathrm{C}}$ & $k_{\mathrm{Fe}-\mathrm{Oxi}}$ & $k_{\mathrm{ZnO}-\mathrm{Fe}}$ \\
\hline$A\left[\min ^{-1}\right]$ & $1.8 \times 10^{7}$ & $3.3 \times 10^{1}$ & $4.0 \cdot\left[\right.$ wt pet $\left.\min ^{-1}\right]$ & $1.8 \times 10^{3}$ \\
\hline$E_{\mathrm{a}}\left[\mathrm{kJ} \mathrm{mol}^{-1}\right]$ & $285.7 \pm 19.2$ & $100.7 \pm 45.1$ & $58.7 \pm 124.9$ & $152.7 \pm 23.3$ \\
\hline
\end{tabular}

Table III. Summary of Individual and General Rate Constants

\begin{tabular}{|c|c|c|c|c|c|c|c|c|}
\hline \multirow[b]{2}{*}{ Temperature (K) } & \multicolumn{2}{|c|}{$\begin{array}{c}k_{\mathrm{ZnO}-\mathrm{C}} \\
{\left[10^{-2} \mathrm{~min}^{-1}\right]}\end{array}$} & \multicolumn{2}{|c|}{$\begin{array}{c}k_{\mathrm{FeO}-\mathrm{C}}-1 \\
{\left[10^{-2} \mathrm{~min}^{-1}\right]}\end{array}$} & \multicolumn{2}{|c|}{$\begin{array}{c}k_{\mathrm{Fe}-\mathrm{Oxi}} \\
{\left[10^{-2} \text { wt pet } \min ^{-1}\right]}\end{array}$} & \multicolumn{2}{|c|}{$\left[10^{-2} \mathrm{~min}^{-1}\right]$} \\
\hline & Individual & General & Individual & General & Individual & General & Individual & General \\
\hline 1695 & 2.7 & 2.8 & 2.2 & 2.6 & 4.5 & 6.3 & 3.1 & 3.5 \\
\hline 1737 & 4.4 & 4.6 & 2.9 & 3.1 & 4.7 & 6.9 & 5.0 & 4.5 \\
\hline 1743 & 4.9 & 5.0 & 3.3 & 3.1 & 9.3 & 7.0 & 5.0 & 4.7 \\
\hline 1757 & 6.0 & 5.8 & 4.0 & 3.3 & 11.2 & 7.2 & 4.9 & 5.1 \\
\hline 1782 & 8.1 & 7.6 & 3.7 & 3.6 & 7.7 & 7.7 & 5.7 & 5.9 \\
\hline 1804 & 9.3 & 9.7 & 3.6 & 4.0 & 5.8 & 8.0 & 6.8 & 6.7 \\
\hline$R^{2}$ & 0.99 & & 0.59 & & 0.07 & & 0.92 & \\
\hline
\end{tabular}

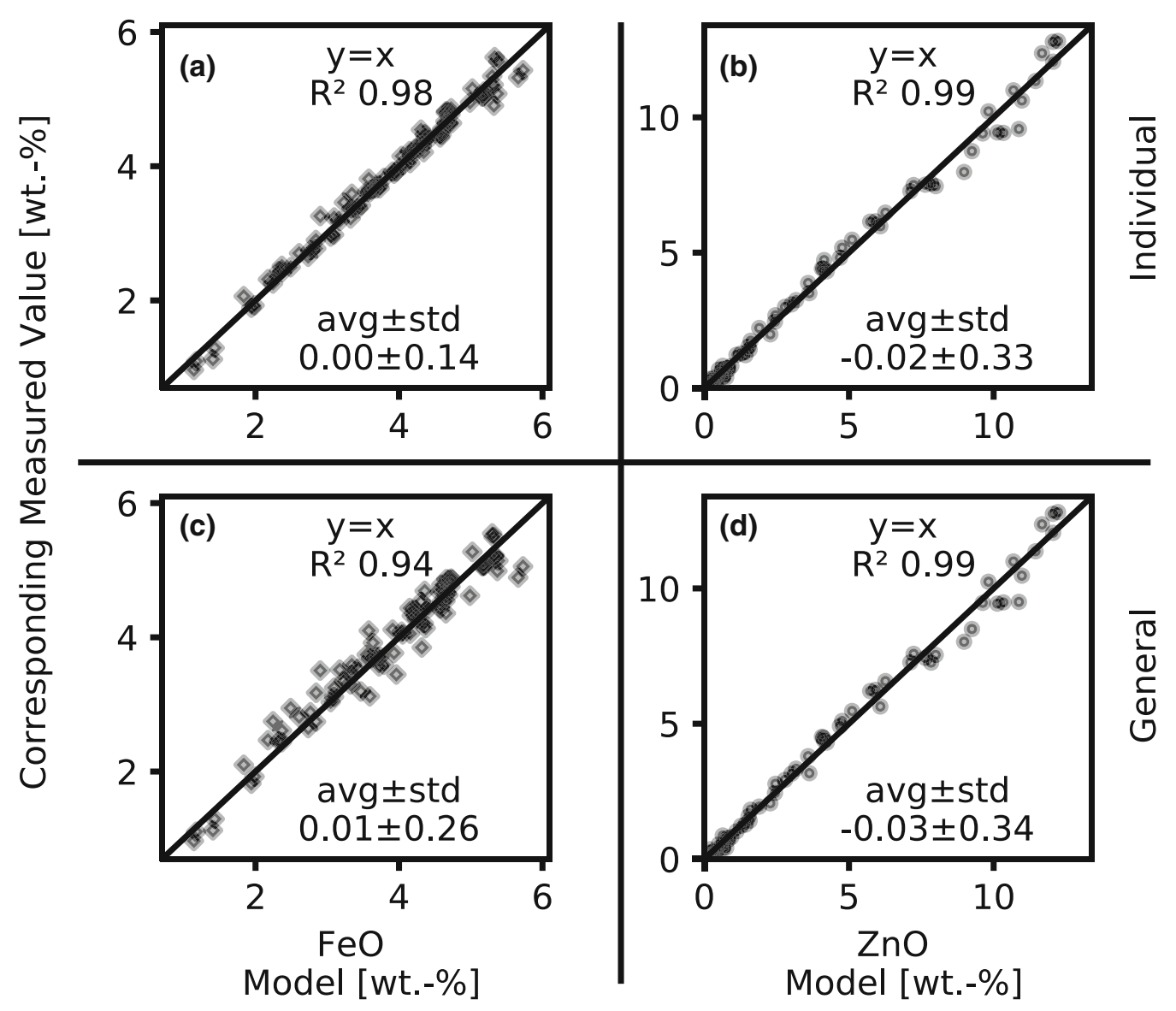

Fig. 4-Scatter plot of the measured effective $\mathrm{FeO}$ and $\mathrm{ZnO}$ concentrations $v s$ calculated model values. The first row shows the deviation between measured and model values for the individual fits (individual) and the second row after applying the Arrhenius correlation to the rate constants (general) (a) $\mathrm{FeO}$ individual fits, (b) $\mathrm{ZnO}$ individual fits, (c) $\mathrm{FeO}$ general fit, (d) $\mathrm{ZnO}$ general fit. 


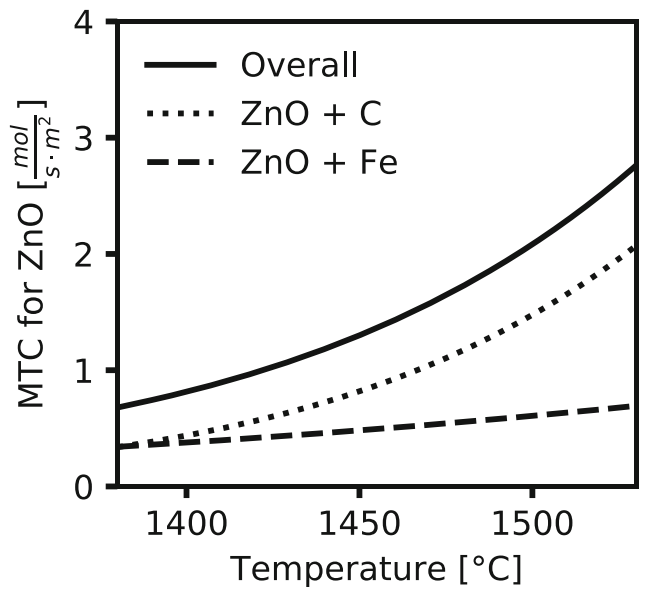

(a)

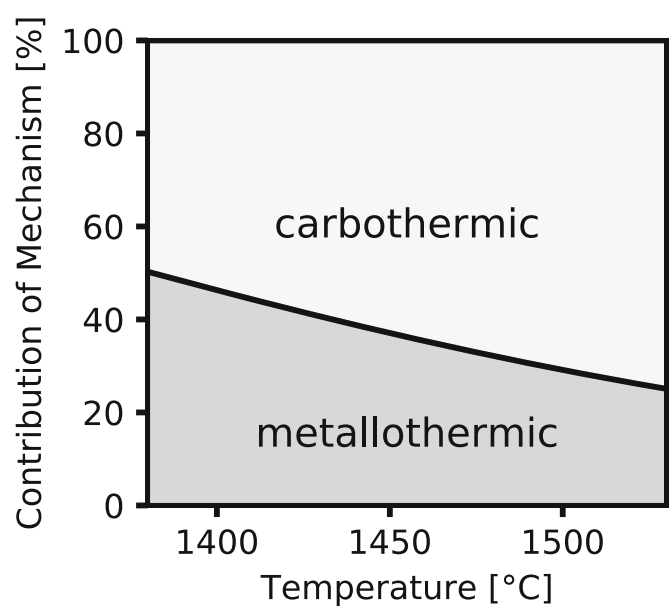

(b)

Fig. 5- (a) MTC for ZnO depending on the process temperature. (b) Share of reaction mechanism for ZnO reduction.

metallothermic reactions. We provide temperature dependent mass transfer coefficients which generally define the reactions of the $\mathrm{ZnO}$ and $\mathrm{FeO}$ reduction.

The applied mathematical model describing the reaction kinetics of a system of reduction reactions is based on a more simple approach described by Leuchtenmueller et al. on the carbothermic chromium oxide reduction. ${ }^{[50]}$ In this study, obtained data of six individual high-temperature reduction experiments were in good agreement (min. $R^{2}=0.94$ ) with the developed kinetic model. The rate constant of the $\mathrm{FeO}$ reverse reaction did not follow the Arrhenius correlation, resulting in more deviation (Figure 4) from the predicted model than the other reactions. This difference was founded in the missing $\mathrm{FeO}$ chemical equilibrium in the slag. However, this does not affect the significance of the $\mathrm{ZnO}$ reduction. Presented kinetic model resulted in the following main findings:

1. We confirm the reported qualitative observations of Donald and Pickles ${ }^{[22]}$ that carbon-saturated molten iron is an effective method to reduce zinc oxide from a molten slag phase. The $\mathrm{ZnO}$ concentrations in the final slag samples were below $0.1 \mathrm{wt}$ pct resulting in $\mathrm{Zn}$ recovery rates higher than 99.9 pct. $\mathrm{FeO}$ reduction rates of the metal-bath process were comparatively slow.

2. The developed kinetic model applied to the metal-bath process proves that the metallothermic $\mathrm{ZnO}$ reduction with $\mathrm{Fe}$ is a major contributor to the overall reaction mechanism. Therefore, our experimentally validated model demonstrates that the $\mathrm{ZnO}$ reduction is a combination of simultaneous carbothermic and metallothermic reactions. The model establishes that two reduction reactions of metal oxides in slags can occur simultaneously (given sufficient thermodynamic driving force), which directly contradicts previous reports, which state that $\mathrm{FeO}$ will be reduced prior to $\mathrm{ZnO} .^{[51]}$
Furthermore, when considering the reduction of $\mathrm{ZnO}$ in contact with a $\mathrm{C}$-saturated liquid Fe melt based solely on thermodynamics, the assumption may prevail that the more noble (less oxygen affine) $\mathrm{Fe}$ does not participate in the reduction reaction. Yet, this study confirms a significant contribution of $\mathrm{Fe}$ to the overall $\mathrm{ZnO}$ reduction.

3. This study applied the combination of a mathematically derived kinetic model verified by experiments to provide quantitative information on the $\mathrm{ZnO}$ reduction mechanism.

The carbothermic reaction exhibited a significantly higher temperature dependency than the metallothermic reaction, which reduced the contribution of the metallothermic reduction to the overall reaction from approximately 50 pct at $1400{ }^{\circ} \mathrm{C}$ to 25 pct at $1500{ }^{\circ} \mathrm{C}$. Such a temperature rise (from $1400{ }^{\circ} \mathrm{C}$ to $1500{ }^{\circ} \mathrm{C}$ ) also increased the total mass transfer of the zinc oxide reduction from approximately 0.7 to $\sim 2.8 \quad[\mathrm{~mol}$ $\mathrm{s}^{-1} \mathrm{~m}^{-2}$ ].

The presented experimental data does not allow the precise determination of the rate limiting step. However, the authors propose that the formation of gaseous zinc at the metal-slag boundary could be limiting the reaction speed. The availability of a carrier gas is assumed to increase the $\mathrm{ZnO}$ reduction. Kim et al. describe in a similar setting improved $\mathrm{ZnO}$ reduction rates at higher $\mathrm{FeO}$ concentrations and proposed a reaction between $\mathrm{ZnO}$ and $\mathrm{FeO}$ to form $\mathrm{Zn}$ and $\mathrm{Fe}_{2} \mathrm{O}_{3}{ }^{[48,49]}$ However, we believe that the elevated kinetics reported by Kim et al. may have been a result of the increased $\mathrm{CO}$ formation, which increased the $\mathrm{Zn}$ gas development.

$\mathrm{Zn}$ containing waste materials, such as EAFD, can contain up to 0.5 pct $\mathrm{Cu}$. During the metal bath process $\mathrm{Cu}$ would accumulate in the $\mathrm{Fe}$-rich metallic phase and produce $\mathrm{Cu}$-contaminated pig iron as by-product. To achieve economic operations the metal bath process should avoid excessive $\mathrm{FeO}$ reduction and produce a 
FeO-rich slag without volatiles $(\mathrm{Zn}, \mathrm{Pb}, \mathrm{Cl})$ and impurities $(\mathrm{Cu})$ which could be recycled in integrated steel mills.

The experimental setup and established model were able to mimic certain aspects of the recycling of zinc-containing industrial wastes, but presented results must be viewed considering following limitations: (1) Only one defined slag composition was investigated; (2) A synthetic slag was used to model an industrial waste composition; (3) A constant slag mass, (4) constant $\mathrm{C}$-concentration in the metal and (5) constant $\mathrm{CO}$ partial pressure were assumed to simplify the mathematical model; (6) Given temperature fluctuations occurred. Future work should focus on these limitations and include the kinetic influence of the slag $\mathrm{FeO}$ concentration.

\section{CONCLUSION}

Our mathematical kinetic model is the first study to fundamentally describe the combined kinetics of three simultaneously occurring reactions of the carbothermic $\mathrm{ZnO}$ reduction with liquid, molten phases including the reduction agents, carbon and iron. We conclude that carbothermic and metallothermic reactions occur simultaneously, and that the metallothermic reduction is a major contributing process tipping the balance towards a more pronounced $\mathrm{ZnO}$ reduction. The presented kinetic model may be used to design a recycling treatment for zinc-containing industrial wastes applying a carbon-saturated iron-bath process.

\section{ACKNOWLEDGMENT}

This work was supported by the Austrian Research Promotion Agency (FFG).

\section{FUNDING}

Open access funding provided by Montanuniversität Leoben.

\section{OPEN ACCESS}

This article is licensed under a Creative Commons Attribution 4.0 International License, which permits use, sharing, adaptation, distribution and reproduction in any medium or format, as long as you give appropriate credit to the original author(s) and the source, provide a link to the Creative Commons licence, and indicate if changes were made. The images or other third party material in this article are included in the article's Creative Commons licence, unless indicated otherwise in a credit line to the material. If material is not included in the article's Creative Commons licence and your intended use is not permitted by statutory regulation or exceeds the permitted use, you will need to obtain permission directly from the copyright holder. To view a copy of this licence, visit http://creativec ommons.org/licenses/by/4.0/.

\section{REFERENCES}

1. S. Spatari, M. Bertram, K. Fuse, T.E. Graedel, and E. Shelov: Resour. Conserv. Recycl., 2003, vol. 39, pp. 137-60.

2. S.R. Taylor: Geochim. Cosmochim. Acta, 1964, vol. 28, pp. 127385.

3. H.-W. Ma, K. Matsubae, K. Nakajima, M.-S. Tsai, K.-H. Shao, P.-C. Chen, C.-H. Lee, and T. Nagasaka: Resour. Conserv. Recycl., 2011, vol. 56, pp. 134-40.

4. G. Meylan and B.K. Reck: Resour. Conserv. Recycl., 2017, vol. 123, pp. 1-10.

5. M.K. Jha, V. Kumar, and R.J. Singh: Resour. Conserv. Recycl., 2001, vol. 33, pp. 1-22.

6. R.L. Nyirenda: Min. Eng., 1991, vol. 4, pp. 1003-25.

7. X. Lin, Z. Peng, J. Yan, Z. Li, J.-Y. Hwang, Y. Zhang, G. Li, and T. Jiang: J. Clean. Prod., 2017, vol. 149, pp. 1079-1100.

8. L.R.P.D.A. Lima and L.A. Bernardez: J. Hazard. Mater., 2011, vol. 189, pp. 692-99.

9. B.-S. Kim, S.-B. Jeong, J.-C. Lee, D. Shin, and N.-I. Moon: Mater. Trans., 2012, vol. 53, pp. 985-90.

10. A.L. Riley, S.E. Pepper, A.J. Canner, S.F. Brown, and M.D. Ogden: Separ. Sci. Technol., 2018, vol. 53, pp. 22-35.

11. R. Remus, M. A. Monsonet, S. Roudier, and L. D. Sancho: Luxembourg: Publications Office of the European Union, 2013, p. 621

12. A.-G. Guézennec, J.-C. Huber, F. Patisson, P. Sessiecq, J.-P. Birat, and D. Ablitzer: Powder Technol., 2005, vol. 157, pp. 2-11.

13. World Steel in Figures 2019.

14. J.G.M.S. Machado, F.A. Brehm, C.A.M. Moraes, C.A.D. Santos, A.C.F. Vilela, and J.B.M.D. Cunha: J. Hazard. Mater., 2006, vol. 136 , pp. $953-60$.

15. C.A. Pickles: Min. Process. Extract. Metall., 2003, vol. 112, pp. 81-89.

16. J.C. Wang, M.T. Hepworth, and K.J. Reid: JOM, 1990, vol. 42, pp. $42-45$.

17. T. Suetens, B. Klaasen, K. van Acker, and B. Blanpain: J. Clean. Product., 2014, vol. 65, pp. 152-67.

18. J. Antrekowitsch, G. Rösler, and S. Steinacker: Chem. Ingen. Tech., 2015, vol. 87, pp. 1498-1503.

19. S. Pauliuk, R.L. Milford, D.B. Müller, and J.M. Allwood: Environ. Sci. Technol., 2013, vol. 47, pp. 3448-54.

20. M. Atkinson and R. Kolarik: Steel Industry Technology Roadmap, 2001.

21. B. Cubukcuoglu and S. Ouki: The Use of Alternative Constituents in Cement-Based Solidification/Stabilisation of Electric Arc Furnace Dust, 2009

22. J.R. Donald and C.A. Pickles: Can. Metall. Q., 1996, vol. 35, pp. 255-67.

23. O.D.A. Hiroshi, T. Ibaraki, and Y. Abe: Nippon Steel Technical Report No. 94, 2006.

24. K. Mager, U. Meurer, B. Garcia-Egocheaga, N. Goicoechea, J. Rutten, W. Saage, and F. Simonetti: Recycling of Metals and Engineercd Materials, Ed. by D. L. Stewart, J. C. Daley, and R. L. Stephens, Wiley, Hoboken, NJ, 2000, pp. 329-44.

25. M. Nakayama: SEAISI Q., 2012, vol. 41, pp. 22-26.

26. E.C. Schoukens, S. Afs et al.: J. South. Afr. Inst. Min. Metall., 1993, vol. 93, pp. 1-7.

27. M.G. Maccagni: J. Sustain. Metall., 2016, vol. 2, pp. 133-40.

28. J.A. Asteljoki, Method for Producing Zinc by Means of Iron Melt Reduction, 0433674 A1.

29. I. Vegas, J.A. Ibañez, J.T. San-José, and A. Urzelai: Waste Manag., 2008, vol. 28, pp. 565-74. 
30. H. Maczek and R. Kola: JOM, 1980, vol. 32, pp. 53-58.

31. P.I. Grudinsky, D.V. Zinoveev, V.G. Dyubanov, and P.A. Kozlov: Inorg. Mater. Appl. Res., 2019, vol. 10, pp. 1220-26.

32. V.I. Matyukhin, O.V. Matyukhin, V.V. Shatsillo, A.V. Matyukhina, and O.S. Koshcheeva: Metallurgist, 2017, vol. 60, pp. 1025 31.

33. S. Sorlini, C. Collivignarelli, G. Plizzari, and M. D. Foglie: In: Proceedings of the "International RILEM Conference on the use of recycled materials in buildings and structures", RILEM publications, Barcelona, 2004, pp. 9-11.

34. G.-S. Lee and Y.J. Song: Min. Eng., 2007, vol. 20, pp. 739-46.

35. O. Ruiz, C. Clemente, M. Alonso, and F.J. Alguacil: J. Hazard. Mater., 2007, vol. 141, pp. 33-36.

36. P. Palimąka, S. Pietrzyk, M. Stępień, K. Ciećko, and I. Nejman: Metals, 2018, vol. 8, p. 547 .

37. C. Lanzerstorfer: J. Clean. Product., 2018, vol. 174, pp. 1-6.

38. S. Itoh, A. Tsubone, K. Matsubae-Yokoyama, K. Nakajima, and T. Nagasaka: ISIJ Int., 2008, vol. 48, pp. 1339-44.

39. R. Chairaksa-Fujimoto, Y. Inoue, N. Umeda, S. Itoh, and T. Nagasaka: Int. J. Miner. Metall. Mater., 2015, vol. 22, pp. 788-97.

40. R. Chairaksa-Fujimoto, K. Maruyama, T. Miki, and T. Nagasaka: Hydrometallurgy, 2016, vol. 159, pp. 120-25.

41. T. Sofilić, A. Rastovcan-Mioc, S. Cerjan-Stefanović, V. Novosel-Radović, and M. Jenko: J. Hazard. Mater., 2004, vol. 109, pp. $59-70$.
42. M.C. Mantovani, C. Takano, and P.M. Büchler: Ironmak. \& Steelmak., 2004, vol. 31, pp. 325-32.

43. Y. Li, Z. Liu, H. Liu, and B. Peng: J. Clean. Prod., 2017, vol. 143, pp. 311-18.

44. W.J. Rankin and S. Wright: Metall. Mater. Trans. B, 1990, vol. 21, pp. 885-97.

45. H.-K. Chen: Scand. J. Metall., 2001, vol. 30, pp. 292-96.

46. B.-S. Kim, J.-M. Yoo, J.-T. Park, and J.-C. Lee: Mater. Trans., 2006, vol. 47, pp. 2421-26.

47. Y. Kuwauchi and M. Barati: ISIJ Int., 2013, vol. 53, pp. 1097-105.

48. J.R. Donald and C.A. Pickles: Metall. Mater. Trans. B, 1996, vol. 27, pp. 363-74.

49. M. Leuchtenmueller, W. Schatzmann, and S. Steinlechner: $J$. Environ. Chem. Eng., 2020, vol. 8, p. 103976.

50. M. Leuchtenmüller, J. Antrekowitsch, and S. Steinlechner: Metall. Mater. Trans. B, 2019, vol. 50, pp. 2221-28.

51. P.A. Kozlov: The Waelz Process, Ore and Metals Publishing House, 2003.

Publisher's Note Springer Nature remains neutral with regard to jurisdictional claims in published maps and institutional affiliations. 